\title{
Efficiency of growth biostimulators in production of planting material of northern white cedar
}

\author{
N.A. Lopachev*, V.T. Lobkov, V.P. Naumkin, and A.L. Bykov \\ Federal State Budgetary Educational Establishment of Higher Education "Orel State Agrarian \\ University named after N.V. Parakhin”, Orel, Russia
}

\begin{abstract}
An assessment of the efficacy of preparations (Kornevin, SP; Albit, TPS; Epin-extra) in the production of planting material of Northern white cedar by vegetative propagation with wood cuttings under the conditions of the Central Black Earth Region of the Russian Federation is given on the example of the Orel region. All the studied preparations had a significant effect on the rooting process of cuttings. The obtained and analyzed data of phenological observations showed that the greatest effect on the acceleration of the onset of the of root formation phase had preparation "Albit, TPS", 3-4 weeks earlier than the control. The number of formed cuttings and their length were also mainly influenced by "Albit, TPS", which increased the average number of roots by 3 pcs., and their average length by $44 \mathrm{~mm}$, in comparison with the control. The effect of the use of the biostimulator "Albit, TPS" had a significant influence on the number of established cuttings, providing 20 rooted cuttings or $28 \%$ more than in the control.
\end{abstract}

\section{Introduction}

A sharp change in climate over the last period of time, environmental disasters - the death of the Aral Sea, the climax state of the Volga, the Kuban, the Ural river and other rivers, caused aridization and salinization of a significant territory of the middle region of the Eurasian continent, which led to the suppression and death of many species of aboriginal phytocenoses. For this reason it is necessary to replace the disappeared native plants with resistant and highly productive wild and cultural introduced species quickly. Therefore, the introduction of plants is an important factor in the restoration of phytocenoses. At the same time, the introduced species are the initial genetic basis for the selection of highly productive and resistant plant varieties. However, the difficulties in the introduction of cultivated and wild plants in most cases are caused by the lack of high-quality planting material.

The lack of planting material arises especially during the introduction of decorative and fruit crops, which are of great importance for horticulture and nursery. The introduced species play a special role and occupy a significant part in the assortment of young plants

\footnotetext{
*Corresponding author: lopachev.nikolai@vandex.ru
} 
grown in gardens, nurseries and household plots. These plants can be of great benefit in the formation of species diversity, rich in useful and biologically active substances in the diet of the population, and satisfy recreational human needs, therefore, the production of planting material for such plants is of great economic importance. Also, an increase in the species diversity of agrocenoses increases its resistance to difficult environments. P. Flombaum in his work on the impact of biodiversity on the productivity and sustainability of ecosystems writes: "We found out that the impact of biodiversity on phytocenoses was greater in natural than in artificial ecosystems. This result confirms that the impact of biodiversity on natural ecosystems may be much greater than it is currently believed" [1].

The accumulation of organic plant matter in general, and conifers in particular, is of particular importance in the modern world, which is under the threat of depletion of the main energy resources. Conifers are of invaluable economic importance as a source of commercial timber, raw materials for papermaking, biologically active substances for various industries. They also play an important role in maintaining the ecological balance of the planet [2].

So Naylor R.L. says about the economic benefits of the introduction: "The most common motivation for intentional introduction was an increase in economic income from local biocenoses. During the period of great geographical discoveries, Europeans transported cultivated plants and livestock with them" [3].

To achieve success in the transfer of new plants useful for people, it is very important to prevent invasive plants from entering new habitats, as well as pests and diseases that may accompany them.

Therefore, it is necessary to study carefully natural habitats, flora adjacent to hypothetical introduced species as well as harmful organisms of this area. So Clay Lancaster in his works writes that: "Among plants there is also a large number of intentional aliens, especially decorative ones. For example, the European Norway maple (Acer platanoides) in the form of green spaces in gardens and parks came to the American continent, and the Canadian maple (Acer negundo), on the contrary, is widely cultivated in Europe, including Russia. At the same time, Norway maple is known as an aggressive, invasive species that threatens native species" [4].

Fruit and berry introduced species brought from the regions with more severe conditions than new ones, acclimatize faster and are often able to increase yields with increased nutritional value of fruits. Decorative crops can change their typical shape, flowering time and quality indicators of plants. It should be remembered that this also applies to harmful organisms. Nowadays, the species and varietal composition of agrocenoses (industrial gardens, parks and household plots) of the Central Black Earth Region of Russia, in particular the Orel region, is rather scarce in comparison with near and far abroad countries, this is partly due to the less developed scientific and practical introduction. That is absolutely unreasonable, because there is the richest species composition of regions with plants suitable for introduction into the Central Black Earth Region of the Russian Federation, both from the territory of the Russian Federation and from other countries.

One of the most promising for the introduction and subsequent production of its planting material in the Orel region and the entire Central Black Earth Region is the coniferous decorative plant Northern white cedar (Thuja occindentalis). The main commercial use of Northern white cedar in the region of its growth is timber [5]. Also, Thuja occidentalis is used in medicine. B. Näser in his work on the study of the therapeutic properties of this plant says: "Many clinical studies have been performed with a herbal medicine containing a special extract of Thuja occidentalis and other immunostimulators, which has demonstrated its therapeutic efficacy and safety in respiratory tract infections" $[6]$. 
Apart from the above, it is worth mentioning that young plants of Northern white cedar planted in an urban environment, as well as near objects requiring environmental supervision, can be used as pollution indicators: "Patterns of bioaccumulation of priority heavy metals (cadmium, lead, copper and zinc) in evergreens reflect the degree of anthropotechnogenic impact on the environment and can determine the prospects for the use of these species as sensitive bioindicators in the implementation of social and hygienic monitoring" [7].

Therefore, one of the limiting factors of introduction is obtaining a sufficient amount of planting material of the introduced species. For the successful introduction of new plant species, it is necessary to work out the technology of their reproduction. Vegetative reproduction of the introduced species makes it possible to introduce a large number of plants into new conditions in a short time, while retaining their beneficial properties and other features of the mother plant. J.D. Curtis describes the reproduction capacity of Northern white cedar as follows: "Northern white cedar can take root from any part of a branch or stem if moisture conditions are favorable. Thus, it often reproduces vegetatively in swamps, especially in poor areas with abundant peat-moss "[8].

Despite the long history of introduction, most of the factors are still poorly understood, and some, against the background of rapid climatic and environmental changes, require constant updating and research monitoring in this area.

G.A. Ritchie defines the boarders of the necessary research in this area as follows: "Relatively few detailed studies have been published, but the field characteristics of the rooted cutting appear to be the same as those of the young plants, provided the donor plants are juvenile. The key research needs are the maintenance of juveniles, the cultivation of the original plants, the improvement of the root system, mechanization and field experiments "[9].

G.A. Yusufov in his work on the reproduction of decorative introduced species writes: "For the introduced species as promising species of the medicinal and decorative gardening, it makes sense to continue comprehensive research in the following areas: ability to reproduce in seed and vegetative ways, phytochemical analysis, developmental phenophases, optimum and reaction rates" [10].

The use of growth and root formation regulators is an important factor for the intensification of the planting material production. It allows to reduce not only the loss of cuttings, but also the rooting time, which, in combination with the use of technologies for growing under cover and propagation by semi-lignified cuttings, allows to get several generations of the introduced species per year [11].

P.S.Kirillov, L.P. Trofimchuk in their works about growth biostimulators write the following: "Due to the high cost, the use of foreign phytohormones in Russia is limited, and their synthetic analogs do not show the desired morphogenetic effect. In this regard, the study of new growth stimulators with high morphogenetic effects attracts more attention of physiologists, biochemists, plant growers involved in the cultivation of plant tissues "[12].

Based on the above, the purpose of our study was to assess the effectiveness and study the impact of biostimulators on reproduction by means of green cuttings of Northern white cedar introduced species in the production of its planting material in the Central Black Earth Region of Russia on the example of the Orel region. To achieve this goal, it was necessary to solve the following tasks:

- to study various aspects of the introduction and biological characteristics of the introduced species;

- to summarize the achievements for the previous period in the field of vegetative propagation of Northern white cedar;

- to master various methods of reproduction of Northern white cedar introduced species; 
- to reveal the peculiarities of rooting of woody cuttings of Northern white cedar in unheated tunnel-type greenhouses in the Central Black Earth Region of Russia on the example of the Orel region;

- to determine the effectiveness of growth regulators in the reproduction of Northern white cedar in the conditions of the Orel region.

\section{Materials and methods}

The research for determining the effectiveness of biostimulators in the reproduction of Northern white cedar were carried out in the Central Black Earth Region of Russia on the example of the Orel Region in the unheated tunnel-type greenhouses. The greenhouses were located on the base of the private entrepreneur (PE) Bykov L.S. of the Trosnyanskiy district. Woody cuttings of Northern white cedar (Thuja occidentalis) cut from a six-yearold mother plant were chosen as the main material during the study.

Northern white cedar is the most popular decorative plant in the Western Europe. Under natural conditions in the North America, it reaches, often on cold swampy soils, a height of $20 \mathrm{~m}$, in culture it is much lower. Its crown is conical; the bark is brown, cracking into flat stripes; skeletal branches are short, horizontal, with numerous, flattened, horizontally located lateral branches, dark green and shiny above. It has scale-like needles; on the central axes of the branches it is spaced, up to $4 \mathrm{~mm}$ long, on the lateral (end) branches it is tightly fitting, up to $2.5 \mathrm{~mm}$ long, ovoid, retused; planar needles are with a distinct piece of gland on the back. The lateral needles are smaller in size, cariniform, the glands are indistinct. The strobiles are on a short stem, elongated, $8 \mathrm{~mm}$ long; first protruding, then drooping; there are 8-10 seed scales, only 4 of which are fruiting; the seeds ripen in the first year. The seed is $3 \mathrm{~mm}$ long, narrow, winged along the edge. It was introduced into Europe in 1534. At present mainly grown are its numerous garden forms [13].

As a control group, some of the cuttings were put into water. The rooting conditions were created in a unheated ground under cover, cassettes for seedlings of 100 cells in each were used as vessels, the microclimate was provided using tunnel-type greenhouses with obligatory shading $(80 \%)$ and regular watering, Figure 1.

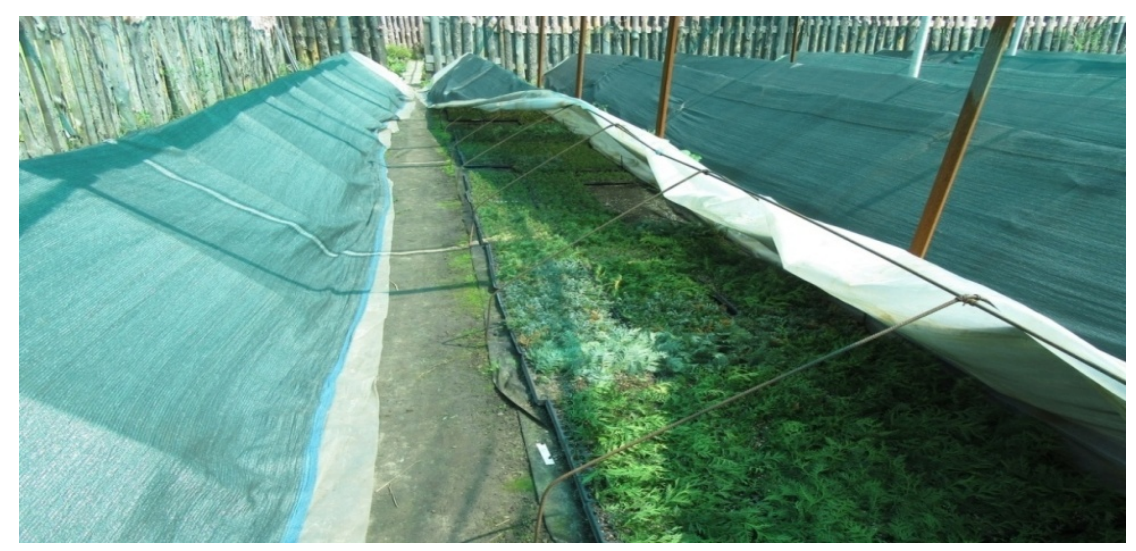

Fig. 1. Tunnel-type greenhouses of the PE Bykov L.S., Orel region, photo taken by the authors.

The woody shoots of the introduced species of Northern white cedar for the preparation of cuttings for rooting in the production of their planting material were cut early in the morning, it was at this time of the day that the maximum saturation of plant tissues with moisture was observed, on May 7, 2021 from one mother plant aged 6 years. We selected for vegetative propagation by cuttings woody stem shoots in 2020-2021, which did not 
have mechanical damage and bacteriological lesions. The cuttings were made the same morning. The shoots were cut into cuttings $7-10 \mathrm{~cm}$ long, leaving the heel (the place where the shoot was attached to the trunk), but cutting off the excess skin (bark) to prevent its decay. To study the effectiveness of the growth stimulators, we prepared 3 solutions of these preparations with the following dosages: "Kornevin, SP" - 1g/l; "Albit, TPS"- 0.03 $\mathrm{g} / \mathrm{l}$; "Epin - extra" $-1 \mathrm{ml} / 1$. After preparing the cuttings, they were immediately placed into the prepared solutions and water for 24 hours, so that the cut was completely immersed in the solution. For soaking, plastic containers of 100 cuttings in each were used, which were placed in a dark place without temperature changes, Figure 2.

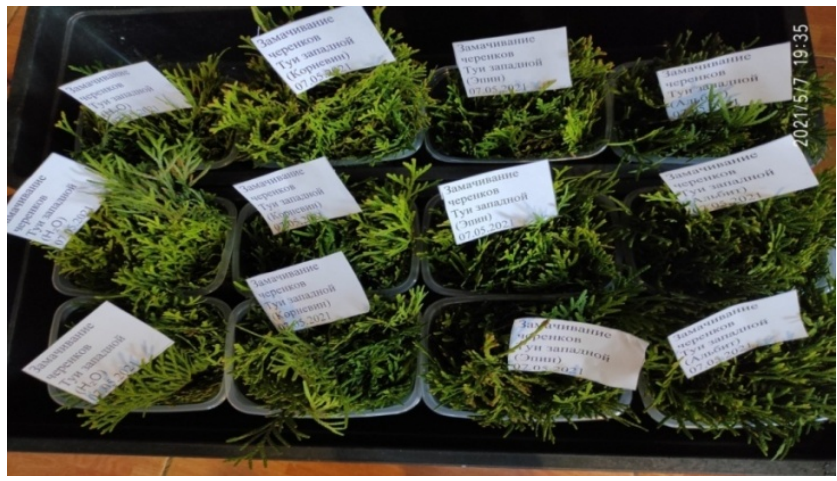

Fig. 2. Soaking of Northern white cedar cuttings in work solutions of biostimulators and in water, photo taken by the authors.

In 24 hours after the cuttings were immersed into the solutions of biostimulators, the treated woody cuttings of the introduced species of Northern white cedar were planted into a soil mixture consisting of a peat substrate $(80 \%)$ with a neutral $\mathrm{pH}$ and agroperlite $(20 \%)$, Figure 3.

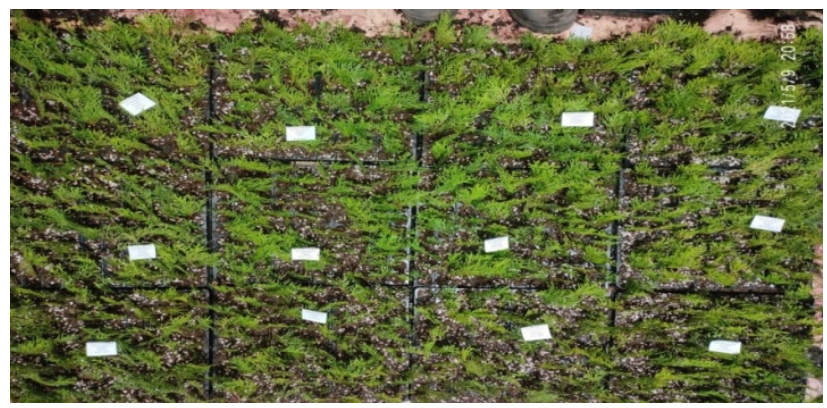

Fig. 3. Northern white cedar cuttings planted in the cassettes with soil mixture on next day after planting, photo taken by the authors.

The cuttings, planted in cassettes of 100 cells in each, were placed in tunnel-type greenhouses with dimming and watering for further rooting.

\section{Results and discussion}

The observation over the phenology of the root development of Northern white cedar cuttings showed that the studied groups entered the phase of root formation at different times, which indicates the influence of the applied biostimulators on this process. The results of phenological observations were presented in the form of Table 1. 
Table 1. The terms of the phenological phases in the studied woody cuttings of the Northern white cedar in the conditions of PE Bykov LS, Orel region, 2021.

\begin{tabular}{|c|c|c|c|c|c|}
\hline \multirow{2}{*}{ No } & \multirow{2}{*}{ Options } & \multicolumn{2}{|c|}{ Callus formation } & \multicolumn{2}{c|}{ Appearance of the first roots } \\
\cline { 3 - 6 } & Dates & $\begin{array}{l}\text { Deviation from } \\
\text { the control, days. }\end{array}$ & Dates & $\begin{array}{l}\text { Deviation from } \\
\text { the control, days. }\end{array}$ \\
\hline 1 & $\mathrm{H}_{2} \mathrm{O}$ (control) & 14.07 & - & 16.08 & - \\
\hline 2 & Kornevin & 27.06 & 17 & 25.07 & 22 \\
\hline 3 & Epin-extra & 05.07 & 9 & 04.08 & 19 \\
\hline 4 & Albit, TPS & 21.06 & 23 & 20.07 & 27 \\
\hline
\end{tabular}

As a result of daily monitoring of the state of the cuttings, after 34 days we found out that cuttings of the 4th group, treated in the solution of the preparation "Albit, TPS", were the first to enter the phase of callus formation, 23 days earlier than cuttings of the control group. A little later, the callus formation began in the cassettes of the 2nd group soaked in "Kornevin's" solution, 17 days earlier than the control. The worst result among the studied biostimulators was demonstrated by "Epin-extra". The cuttings treated with this preparation began to form callus 9 days earlier than the control group. In the control group, callus appeared on the 68 th day.

The phase of callus formation is followed by the phase of the appearance of the first roots. Due to the fact that the callus appeared on the cuttings of the 4th group treated with the "Albit" solution much earlier, the first roots, as expected, began to grow earlier in this group, on the 74th day after planting, which is 27 days earlier than the control. A little later, the first roots began to grow in the cuttings of the 2 nd group, on the 79 th day, which is 22 days earlier than in the cuttings of the control group. The first roots in the 3rd group began to form on the 82 day after planting, 19 days earlier than the control, but much later than in other experimental groups. In the control group, the cuttings began to form the root system on day 101. The phenological observations of the phases of callus formation and appearance of the first roots showed that deviations from the control in the studied groups were quite significant. It proves the effectiveness of applying these preparations when rooting cuttings of Northern white cedar introduced species in the production of planting material in the Central Black Earth Region of the Russian Federation.

The development of the root system is the most important factor, which the success of obtaining plants from the rooted cuttings during vegetative propagation depends on. Poor development of the root system is the reason for poor survival rate during transplantation, low winter hardiness of the rooted cuttings and low quality of planting material [14].

In 120 days after cutting of graftage, we selected 10 cuttings from each cassette. Then we evaluated the root system, especially the length and number of root. We presented the data obtained in the form of Table 2.

Table 2. The effect of growth biostimulators on the growth and development of roots in the woody cuttings of Northern white cedar in the conditions of PE Bykov L.S., Orel region, 2021.

\begin{tabular}{|c|c|c|c|c|c|c|c|}
\hline \multirow[t]{2}{*}{ No } & \multirow[t]{2}{*}{ Options } & \multirow[t]{2}{*}{$\begin{array}{l}\text { Average number of } \\
\text { roots, pcs/plant. }\end{array}$} & \multicolumn{2}{|c|}{$\begin{array}{l}\text { Deviation from the } \\
\text { control }\end{array}$} & \multirow[t]{2}{*}{$\begin{array}{l}\text { Average length of } \\
\text { the roots, } \mathrm{mm}\end{array}$} & \multicolumn{2}{|c|}{$\begin{array}{c}\text { Deviation from } \\
\text { the control }\end{array}$} \\
\hline & & & pcs/plant. & $\%$ & & $\mathrm{~mm}$ & $\%$ \\
\hline 1 & $\mathrm{H}_{2} \mathrm{O}$ (control) & 3 & - & - & 13 & - & - \\
\hline 2 & Kornevin & 5 & 2 & 67 & 34 & 21 & 162 \\
\hline \begin{tabular}{|l|}
3 \\
\end{tabular} & Epin-extra & 4 & 1 & 33 & 22 & 9 & 69 \\
\hline \begin{tabular}{|l|}
4 \\
\end{tabular} & Albit, TPS & 6 & 3 & 100 & 57 & 44 & 338 \\
\hline
\end{tabular}

In the course of our study, as Table 2 shows, all the tested preparations provided a significant increase not only in the average number of roots, but also in their average length. So the most effective for the growth of the root system was the preparation "Albit, 
TPS" +3 roots or $67 \%$ and $+44 \mathrm{~mm}$ to the length or $338 \%$, compared with the control. "Kornevin" is inferior to "Albit" by 1 root or $33 \%$, and in addition to the length of the roots by $23 \mathrm{~mm}$ or $176 \%$. Of all the investigated preparations "Epin-extra" showed the least effect on the growth and development of the root system, the number of roots in this group is only 1 root or $33 \%$ more than the control, and their average length is $9 \mathrm{~mm}$ or $69 \%$ longer than in the control.

Figures 4 and 5 show root systems of the rooted cuttings of the control group and the cuttings treated with the preparation "Albit, TPS".

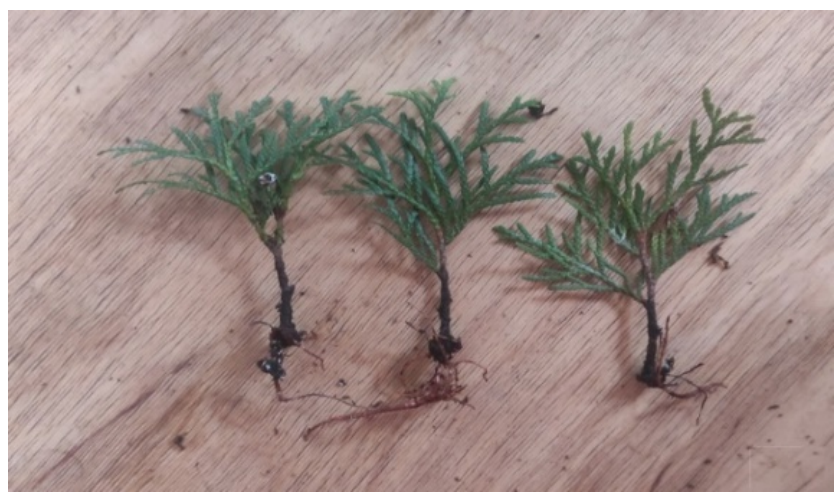

Fig. 4. Root system of Northern white cedar cuttings from the control group, rooted under the conditions of PE Bykov L.S., Orel region, photo taken by the author.

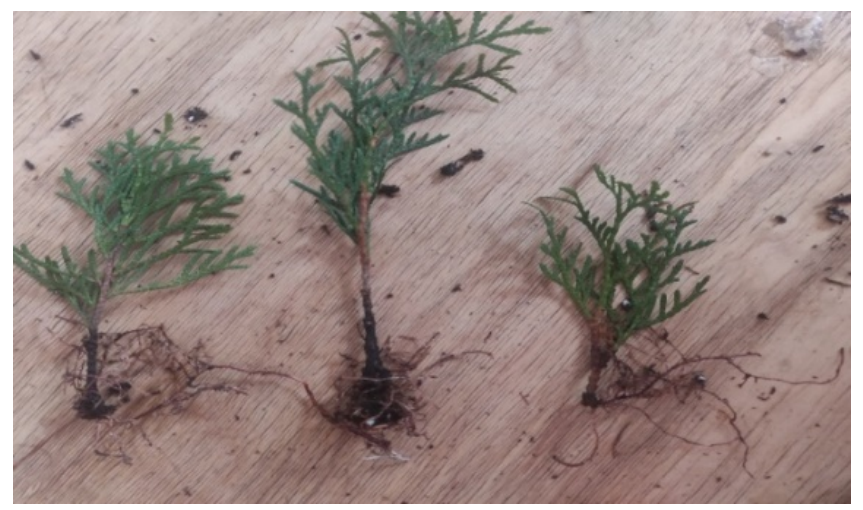

Fig. 5. Root system of Northern white cedar cuttings treated with the preparation "Albit", rooted under the conditions of PE Bykov L.S., Orel region, photo taken by the author.

The main indicator of the effectiveness of the rooting of cuttings during reproduction is the portion of cuttings that have formed a viable root system. Therefore, it was necessary to count the cuttings rooted in each cassette. The data on the number of the rooted cuttings are shown in the form of Table 3.

Table 3. Influence of the biostimulators on the survival ability of woody cuttings of Northern white cedar in the conditions of PE Bykov L.S., Orel region, 2021.

\begin{tabular}{|c|c|c|c|c|c|}
\hline \multirow{2}{*}{ No } & Options & $\begin{array}{c}\text { Average number } \\
\text { of the survived }\end{array}$ & \multicolumn{2}{|c|}{ Deviation from the control } & Group \\
\cline { 4 - 6 } & & $\begin{array}{c}\text { cuttings in the } \\
\text { cassette, pcs }\end{array}$ & pcs. & $\%$ & \\
\hline 1 & $\mathrm{H}_{2} \mathrm{O}$ (control) & 72 & - & - & $\mathrm{I}$ \\
\hline
\end{tabular}




\begin{tabular}{|c|c|c|c|c|c|}
\cline { 3 - 5 } 2 & Kornevin & 84 & 12 & 17 & I \\
\hline 3 & Epin-extra & 78 & 6 & 8 & I \\
\hline 4 & Albit, TPS & 92 & 20 & 28 & I \\
\hline & $L S D_{05}$ & - & 5,1 & 7,1 & \\
\hline
\end{tabular}

In our experience, as Table 3 shows, all the biostimulators provide a significant increase in the survival rate of Northern white cedar cuttings. But the highest effect is provided by "Albit, TPS" +20 rooted cuttings or $28 \%$ compared to the control. "Kornevin, SP" is inferior to "Albit, TPS" by 8 cuttings or $11 \%$. "Epin-extra" provided the lowest survival rate: only 6 cuttings more or $8.3 \%$ compared to the control.

\section{Conclusions}

1. An important factor for increasing the efficiency of the production of Northern white cedar planting material is application of growth stimulators. Their usage allows to accelerate the rate of production of planting material significantly, expand the distribution area of Northern white cedar, restore or provide a basis for new phytocenoses, which is of particular importance when restoring flora in areas affected by the environmental disasters. And such growth biostimulators as "Albit, TPS", due to their effectiveness and wide range of applications for a great variety of crops, will soon replace obsolete preparations.

2. The use of stimulators accelerates the growth and development of plants. The most effective was the use of biostimulator "Albit, TPS". Its use will significantly accelerate the growth and development phases of plants, the callus and primary roots formation begins 34 weeks earlier.

3. "Albit, TPS" also stimulates further development of the woody roots, as the cuttings of Northern white cedar treated with this preparation have formed roots by 3 or $67 \%$ more than in the control group. And the increase in their length was $44 \mathrm{~mm}$ or $338 \%$, compared with the control.

4. The use of the biostimulator "Albit, TPS" had a significant impact on the number of established cuttings, providing 20 rooted cuttings or $28 \%$ more than in the control.

\section{References}

1. P.Flombaum, O.E. Sala, Proc of the Nat Acad of Sc, 105(16), 6087-6090 (2008)

2. M.S. Lazareva, Forestry with the basics of botany and dendrology: textbook (Minsk, RIPO, 2016)

3. R.L. Naylor, S.L. Williams, D.R. Strong, Sc, 294, 1655-56 (2001)

4. C. Lancaster, Handbook of Prospect Park (Long Island University Press, 1972) ISBN 0-913252-06-9

5. W.F. Johnston, M. J. Hyvarinen, Northern white-cedar-an American wood. USDA Forest Service, FS-227 (Washington, DC, 1979)

6. B. Naser, Ev-bas compl \& alter med, 2(1), 69-78 (2005)

7. S.V. Skupnevskiy, V.N. Rakitskiy, T.A. Sinitskaya, I.A. Nikolaev, V.V.Tsagaeva, Hyg \& San, 669-672 (2000)

8. J.D. Curtis, Ecol, 27, 23-36 (1946)

9. G.A. Ritchie G. A, New For, 5(3), 247-275 (1991)

10. G.A. Yusufov, S of Rus: ec, dev, 1, 28-30 (2009) 
11. N.A Lopachev, A.L. Bykov A.L, Bull of the Kur St Agr Ac, 4, 57-63 (2021).

12. P.S. Kirillov, L.P. Trofimuk, Biol Com, 4, 62-74 (2016).

13. $\mathrm{Yu}$. N. Karpun, G.F. Perfilieva, Classification of garden forms of Northern white cedar (Thuja occidentalis L.) (Hortus botanicus, 2004)

14. Zh. A. Kokh, Yu. A. Litovka, P.V. Makolova, K.A. Shabanova, I.N, Chem of veg r mat, 4, $395-403$ (2020) 